ISSN (print): 1698-6180. ISSN (online): 1886-7995

www.ucm.es/info/estratig/journal.htm

Journal of Iberian Geology 38 (1) 2012: 209-223

http://dx.doi.org/10.5209/rev_JIGE.2012.v38.n1.39215

\title{
Main active faults in the Granada and Guadix-Baza Basins (Betic Cordillera)
}

\author{
Principales fallas activas de las Cuencas de Granada y Guadix-Baza \\ (Cordillera Bética)
}

\author{
C. Sanz de Galdeano*1, F.J. García-Tortosa ${ }^{2}$, J.A. Peláez ${ }^{3}$, P. Alfaro ${ }^{4}$, J.M. Azañón ${ }^{1,5}$, J. Galindo- \\ Zaldívar ${ }^{1,5}$, C. López Casado ${ }^{6}$, A.C. López Garrido ${ }^{1}$, J. Rodríguez-Fernández ${ }^{1}$, P. Ruano ${ }^{1,5}$ \\ ${ }^{1}$ IACT (CSIC-UGR), Facultad de Ciencias, Univ. de Granada. Campus Fuentenueva, s/n. 18071-Granada, Spain \\ csanz@ugr.es; jazanon@ugr.es; jgalindo@ugr.es; aclopez@ugr.es; jrodrig@ugr.es; pruano@ugr.es \\ ${ }^{2}$ Dpto. de Geología, Univ. de Jaén. Campus de Las Lagunillas, s/n. Edificio B3-322. 23071-Jaén, Spain. \\ gtortosa@ujaen.es \\ ${ }^{3}$ Dpto. de Física, Univ. de Jaén. Campus de Las Lagunillas, s/n. Edificio A3. 23071-Jaén, Spain \\ japelaez@ujaen.es \\ ${ }^{4}$ Dpto. de Ciencias de la Tierra y del Medio Ambiente, Univ. de Alicante. Apdo. de correos 99. 03080-Alicante, Spain \\ pedro.alfaro@ua.es \\ ${ }^{5}$ Dpto. de Geodinámica, Univ. de Granada. Campus Fuentenueva, s/n. 18071-Granada, Spain. \\ ${ }^{6}$ Dpto. de Física Teórica y del Cosmos, Univ. de Granada. Campus de Fuentenueva, s/n. 18071-Granada, Spain \\ clcasado@ugr.es \\ *Corresponding author
}

Received: 13/06/2011 / Accepted: 25/02/2012

\begin{abstract}
The Granada and Guadix-Baza Basins, the largest Neogene-Quaternary intramontane basins of the Betic Cordillera (southern Spain), undergo active deformation with an associated moderate level of seismic activity. This deformation is controlled by a NNW$\mathrm{SSE}$ compressive regime and an approximate orthogonal tensional regime. The compression produced $\mathrm{N} 70^{\circ} \mathrm{E}$ to $\mathrm{E}-\mathrm{W}$ folds of several scales, the Sierra Nevada antiform being the largest one. The tension is accommodated mainly by NW-SE active normal faults, the most notable being the Baza Fault, in the Guadix-Baza Basin, and the Granada, Sierra Elvira-Dílar and Padul-Dúrcal Faults, in the Granada Basin. In addition, other active faults with different orientations also exist, such as the Alfahuara-Botardo and the Galera faults in the Guadix-Baza Basin, and the Huenes, Obéilar-Pinos Puente and N of Sierra Tejeda Faults in the Granada Basin. Moreover, in several sectors, the presence of orthogonal normal fault sets suggests alternating trends or even radial extension. Slip rates of these active faults, based on geologic markers, vary between 0.06 and $0.5 \mathrm{~mm} /$ year. Estimates for the maximum expected magnitude of earthquakes caused by these faults vary between $\mathrm{M}_{\mathrm{w}} 6.0$ and 7.0. The $\mathrm{N}$ of Sierra Tejeda and the Baza Faults, the larg-
\end{abstract}


est faults in the Granada and Guadix-Baza Basins, respectively, have the greatest seismic potential. They could cause events up to a magnitude of $\mathrm{M}_{\mathrm{w}} 6.5-7.0$, although their reference earthquakes, computed for a return period of 475 years, are on the order of $\mathrm{M}_{\mathrm{w}}$ 5.0-5.5.

Keywords: Active Tectonics, seismotectonics, Granada Basin, Guadix-Baza Basin, Betic Cordillera.

\section{Resumen}

Las Cuencas de Granada y Guadix-Baza, las mayores cuencas intramontañosas del Neógeno y Cuaternario de la Cordillera Bética (sur de España), experimentan una deformación activa y tienen asociada una actividad sísmica moderada. La deformación está controlada por una compresión NNO-SSE y una tensión aproximadamente perpendicular. La compresión ha formado pliegues de dirección $\mathrm{N} 70^{\circ} \mathrm{E}$ a E-O de muy diferentes tamaños, siendo el antiforme de Sierra Nevada el mayor. La tensión se acomoda sobre todo por fallas normales NO-SE, siendo las más notables de ellas la falla de Baza, en la cuenca de Guadix-Baza, y las de Granada, Sierra Elvira-Dílar y Padul-Dúrcal, en la cuenca de Granada. Además, existen otras fallas activas con diferentes orientaciones, tales como la de Alfahuara-Botardo y la de Galera en la cuenca de Guadix-Baza y las de Huenes, Obéilar-Pinos Puente y norte de Sierra Tejeda en la cuenca de Granada. Además, en varios sectores, la presencia de juegos de fallas ortogonales sugiere cambios en el elipsoide de esfuerzos e incluso una extensión radial. Las tasas de desplazamiento de estas fallas activas, calculadas a partir de marcadores geológicos, varían entre 0,06 y $0,5 \mathrm{~mm} /$ año. La estimación del potencial sísmico indica que la máxima magnitud esperable de los terremotos producidos por estas fallas varía entre $\mathrm{M}_{\mathrm{w}} 6,0$ y 7,0. La falla del $\mathrm{N}$ de Sierra Tejeda y la de Baza, las mayores respectivamente en las Cuencas de Granada y Guadix-Baza, tienen el mayor potencial sísmico. Podrían causar eventos con magnitudes del orden de $M_{w}$ 6,5-7,0, aunque sus terremotos de referencia para un periodo de retorno de 475 años son del orden de $M_{w}$ 5,0-5,5.

Palabras clave: Tectónica activa, sismotectónica, cuenca de Granada, cuenca de Guadix-Baza.

\section{Introduction}

The Granada and Guadix-Baza Basins are located in one of the most seismically active zones of the Iberian Peninsula (Fig. 1). This area is characterized by: (1) the lowest minimum Bouguer anomaly values in the entire Betic Cordillera and a crustal thickness between 34 and $38 \mathrm{~km}$ (according to Banda et al., 1993); (2) the highest relief of the Iberian Peninsula as well as the maximum uplift rates of $0.5 \mathrm{~mm} /$ year in Sierra Nevada (Sanz de Galdeano and López Garrido, 1999; Braga et al., 2003; Sanz de Galdeano and Alfaro, 2004) and the highest fluvial incision rates (Pérez-Peña et al., 2009a; 2009b); (3) notable depocentres, such as that of the Pinos PuenteSanta Fe, with Tortonian marine deposits located $1200 \mathrm{~m}$ below sea level in the Granada Basin (Rodríguez-Fernández and Sanz de Galdeano, 2006), and other similar ones located in the Baza sub-basin (Alfaro et al., 2008); (4) the last destructive earthquake in the Iberian Peninsula, the well-known 1884 Andalusian earthquake; (5) the highest instrumental seismicity rate of the Iberian Peninsula (Peláez et al., 2003; Sanz de Galdeano et al., 2003; Sanz de Galdeano and Peláez, 2011), and (6) the highest seismic hazard of the Iberian Peninsula, according to the Spanish Building Code. The last three points pertain to the Granada Basin.

The aim of this paper, taking into account the previous characteristics, is to summarize the active faults of the Granada and Guadix-Baza Basins and their seismic potential.

\subsection{Geodynamic setting}

From the late Miocene to the present (the neotectonic period in the western Mediterranean), the region has been subjected to a compressive stress field running NNW-SSE with an associated ENE-WSW tension (Galindo-Zaldívar et al., 1999; Sanz de Galdeano et al., 2010). The compressive regional stress field, related to the approximately NW-SE convergence of the Eurasian and African plates, has led to folding of the basal metamorphic rocks of the Betic Internal Zones as well as the Neogene-Quaternary sedimentary infill. Especially noteworthy is the NE-SW antiform of the Sierra Nevada. The uplift of this sector of the Cordillera, amounting to at least $4000 \mathrm{~m}$ (Sanz de Galdeano and López-Garrido, 1999), began some 8-9 million years ago (Johnson et al., 1997), is responsible for the present day relief of the Sierra Nevada, separating the Granada and Guadix-Baza Basins.

Tensional deformations were accommodated mainly by NW-SE normal faults. In many cases, the extension was much more conspicuous than the compression and, in some cases, particularly in the area of the Sierra Nevada, a radial extension pattern occurred, in such a way that all the sets of faults sometimes moved as normal faults.

Linked to this progressive uplift, during the late Neogene, both basins became isolated from the sea, beginning their endorheic character.

Many of the faults are located on the borders of the basins, particularly in those on the W and NW borders of the Sierra Nevada, encouraging differential vertical 


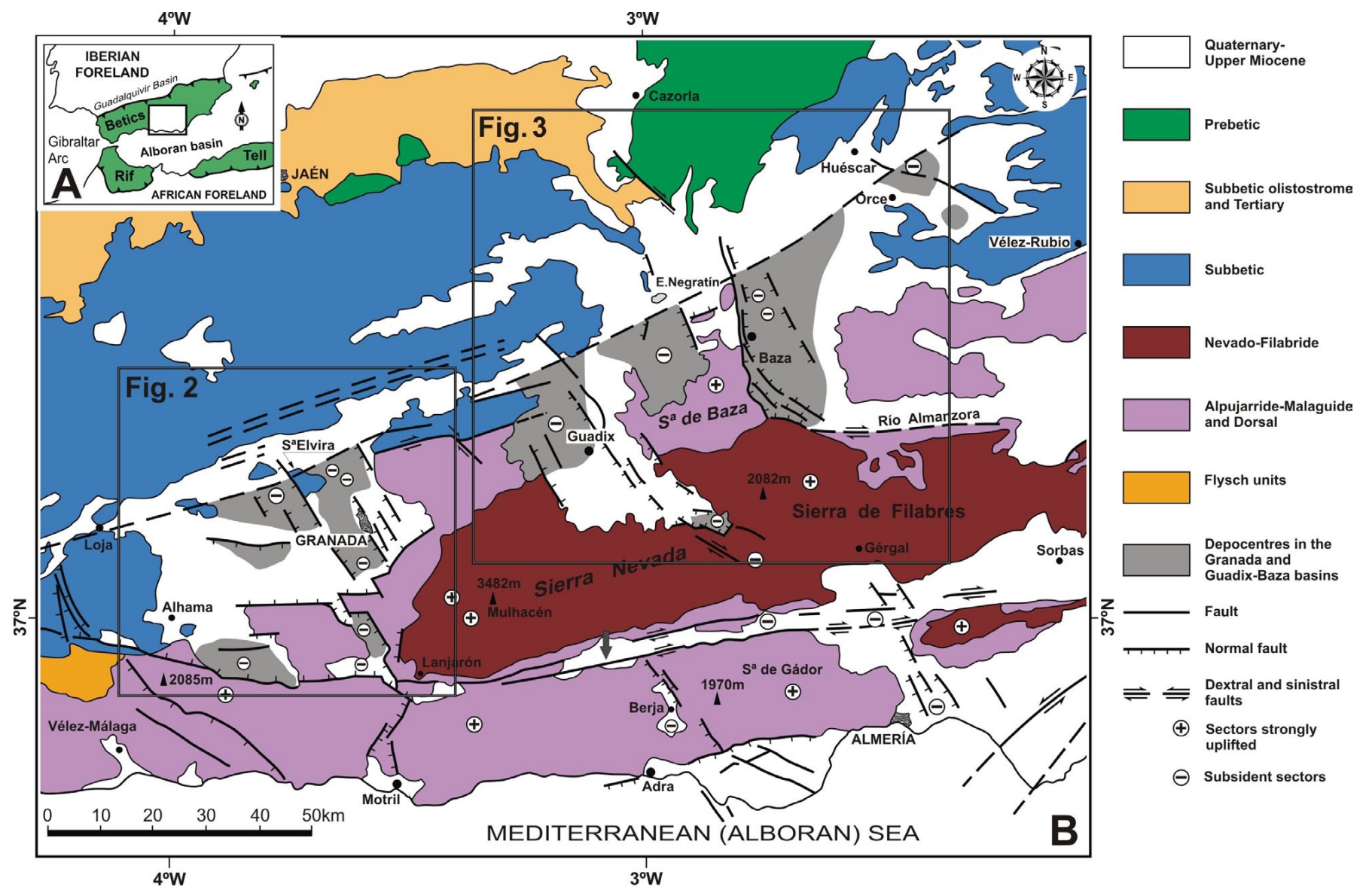

Fig. 1. Regional setting of the Granada and Guadix-Baza Basins. A: location of the study area in the Betic Cordillera, southern Spain. The small square indicates the position of B. B: geological sketch of the central part of the Betics. The squares mark the position of the Granada and Guadix-Baza Basins.

Fig. 1. Situación regional de las Cuencas de Granada y Guadix-Baza. A: situación de ambas cuencas en las Béticas, sur de España. El recuadro pequeño indica la posición de B. B: Esquema geológico del sector central de las Béticas. Los recuadros marcan la posición de las Cuencas de Granada y Guadix-Baza.

movements. Also, large faults developed in the interior of the basins, some of which at present show diverse tectonic, morphologic or seismic features that allow them to be considered as active faults.

\subsection{Main geological features of the Granada and Guadix-Baza Basins}

Both of these intramontane basins developed at the contact between the External, to the north, and Internal, to the south, zones of the Betic Cordillera.

The Granada Basin (Fig. 2), the second largest intramontane basin of the cordillera, has probably the highest tectonic activity and seismic rate of the Iberian Peninsula. This tectonic activity has formed five depocentres (Cubillas, Pinos Puente, Granada, Arenas del Rey, and Padul-Dúrcal; Rodríguez-Fernández and Sanz de Galdeano, 2006). All of these are controlled by high-angle
NW-SE faults and are situated in the central and eastern part of the basin, with the exception of that of the Arenas del Rey, controlled mainly by E-W faults and located to the south. In addition to these features, the eastern border of the basin (western end of Sierra Nevada) shows high tectonic activity, as indicated by the present pattern of strong fluvial incision (Pérez-Peña et al., 2009a). Galindo-Zaldívar et al. (1999) deduced the existence of an extensional detachment, which is the main compensation level of the high-angle normal faults. This detachment is located at approximately 9 to $16 \mathrm{~km}$ deep in the NE of the Granada Basin, while it is progressively deeper towards the west, between 20 and $25 \mathrm{~km}$ deep in the SW sector of the basin.

The Guadix-Baza Basin, with more than $4000 \mathrm{~km}^{2}$, is the largest intramontane basin of the Betic Cordillera (Fig. 3). Its endorheic character persisted till the late Pleistocene (Viseras, 1991; García Tortosa et al., 2011). The 
basin is divided in two sub-basins according to its sedimentary facies, the Guadix sub-basin to the west, which is largely filled with fluvial sediments (Viseras, 1991), and the Baza sub-basin to the east, with a predominance of lacustrine sediments (Vera 1970, Gibert et al. 2007). This distribution is due to the tectonic control of the Baza Fault (Alfaro et al., 2008; García Tortosa et al., 2008a). This fault is the limit between the two sub-basins and its movements caused the subsidence of the hanging wall, with the development of a large lake in the eastern part of the basin (the Baza sub-basin) that existed till the late Pleistocene. The sequence is capped by a $0.5-1 \mathrm{~m}$-thick calcrete interpreted as a glacis surface, which outcrops in a widespread area (more than $1200 \mathrm{~km}^{2}$ ) of the Guadix Basin and is one of the best markers of the recent deformation in the basin (García Tortosa et al., 2011). Its age ranges between 600 and $205 \mathrm{ka}$ (Scott and Gibert, 2009; Díaz-Hernández and Julià, 2006). The topmost laminar horizons of the calcrete, which are pedogenic in origin, have been dated at $45 \mathrm{ka}$ (Azañón et al., 2006; Pérez Peña et al., 2009b).

\subsection{Seismic activity}

Seismicity in the Betic Cordillera is defined by the contact between the Eurasian and the African plates. Broadly, the Betic Cordillera is characterized by a broad low to moderate background seismicity that defines a low to moderate seismic hazard (Fig. 4; Peláez and López Casado, 2002). In addition, the historical period is marked by several destructive earthquakes. In most cases, it is not possible to find a clear link between the main epicentres and the main fault observed on the surface, although in some instances significant earthquake clusters have been linked to the main fault system.

The Granada Basin may be the most seismically active area in the entire Iberian Peninsula, having a significant level of low-magnitude earthquakes distributed from 10 to $25 \mathrm{~km}$ in depth. Instead, the most energetic earthquakes are clearly associated with the most active fault areas, those bordering the Granada Basin to the south, east, and west. This area has experienced some strong earthquakes throughout history. Two destructive events in the Betics are the 1884 Andalusian earthquake (with felt intensities IX-X, also called the 1884 Arenas del Rey or the Alhama de Granada earthquake), and the earlier $1431 \mathrm{~S}$ Granada earthquake (VIII-IX). In fact, the 1884 earthquake, with an assigned macroseismic magnitude of the order of $M_{w}$ 6.5 , has been one of three earthquakes in the Betics felt with intensity IX-X. Its location is clearly associated with the $\mathrm{N}$ of Sierra Tejeda Fault (Reicherter et al., 2003).
The most significant instrumental events located in the Granada Basin were the 1955 SW Armilla $\left(m_{b} 5.1\right.$, VII), formerly called the $1955 \mathrm{La}$ Zubia earthquake, and the 1956 NW Purchil ( $m_{b}$ 5.0, VIII) earthquakes. Both of them, as well as many earthquakes located in the basin with magnitude greater than 4.0, are associated with the NW-SE fault system to the north-west of the basin.

Earthquake swarms are frequent in this region. In the instrumental period, for example, the 1985 Loja and the 1988 Agrón seismic swarms are notable. The main earthquakes of these two swarms had magnitudes of $m_{D}$ 3.9 and $m_{D} 4.0$, respectively. More than 300 events were identified for each of these swarms.

In the Guadix-Baza Basin, the seismicity rate is clearly lower than in the Granada Basin. Earthquakes are located mostly in the Baza sub-basin. They are shallow events, and in this region a clearer relation appears between earthquakes and fault systems. The only significant historic earthquake was the 1531 Baza earthquake (VIII-IX), which was probably related to the Baza Fault. If site effects are not considered, this event would have a magnitude of the order of $M_{w} 6.0$.

The instrumental events located in this region, with some exception, are low-magnitude earthquakes. The two events with the highest magnitude were the 1962 SE Caniles $\left(m_{b L g} 4.7\right)$ and the 1964 SW Galera $\left(m_{b L g} 4.8\right)$ earthquakes. The latter was felt with intensity VIII. The 1962 earthquake appears to have been associated with the Caniles Fault, and the 1964 earthquake with the Galera Fault. In the Guadix sub-basin, the most remarkable event is the 1935 Huélago $\left(m_{D} 4.2\right)$ earthquake, an event barely felt.

\section{Active faults in the Granada Basin}

In the Granada Basin (Fig. 2), many faults affect late Miocene to Quaternary sediments, having a clearly neotectonic character. However, some do not show clear evidence of recent movements and thus cannot be considered active. This is the case of some $N 70^{\circ} \mathrm{E}$ to $\mathrm{E}-\mathrm{W}$ faults, and even of some NW-SE faults situated on the NE border of the basin. Other faults affect Quaternary sediments, showing geomorphologic evidence of recent displacements or seismicity associated with them. These are the active faults, although in this study, we have considered only the main ones (longer than $10 \mathrm{~km}$ ) with a total of 14 faults (Table 1). For a more complete list of faults, active and probably active, see Sanz de Galdeano et al. (2001, 2003) and Sanz de Galdeano and Peláez (2011). Several faults might be connected, as they are geometrically aligned, but we lack firm evidence of this 


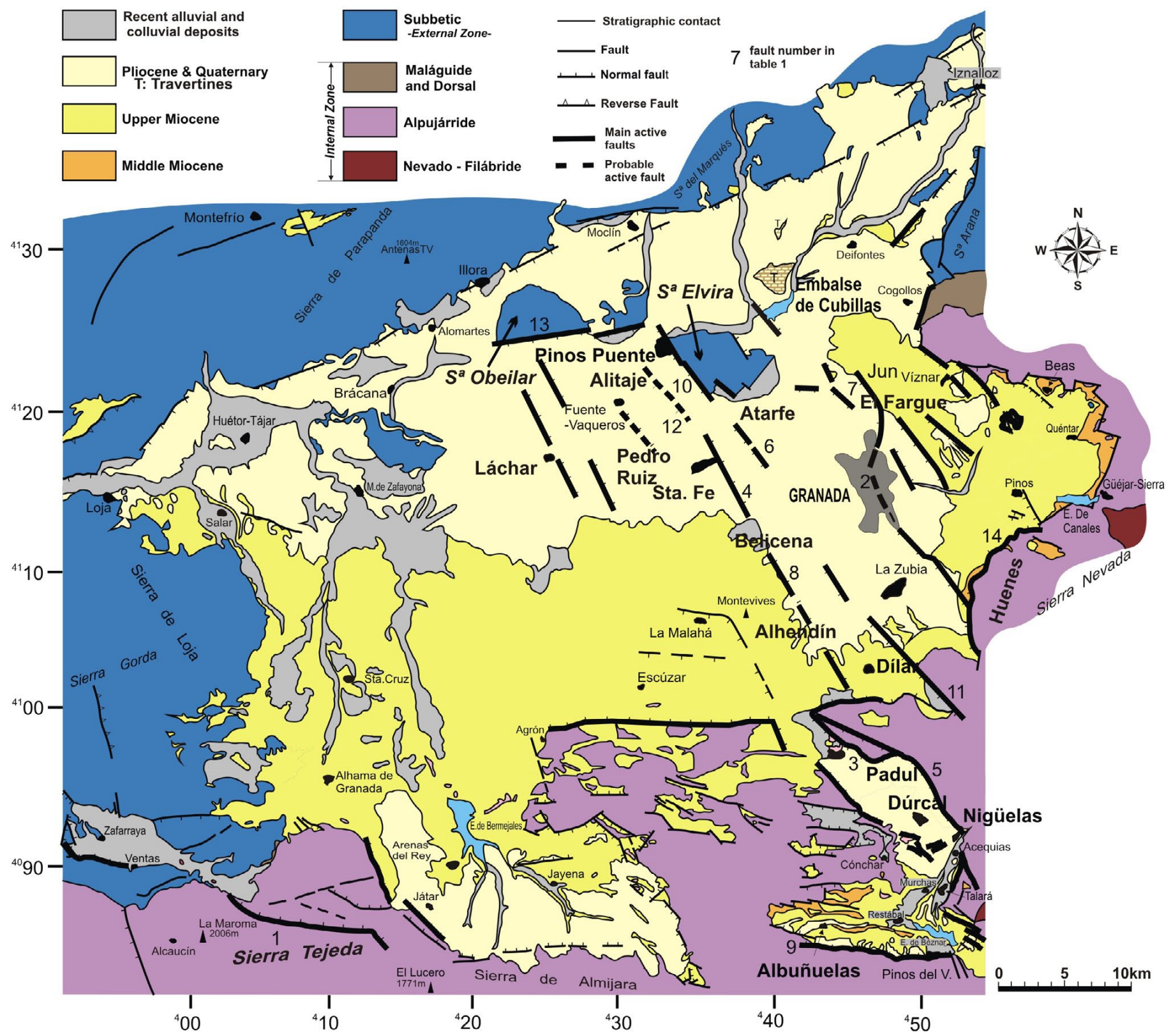

Fig. 2. Simplified geologic map of the Granada Basin. Its position is marked on Figure 1. The numbers correspond to faults described in Table 1.

Fig. 2. Mapa geológico simplificado de la cuenca de Granada. Su posición se indica en la Figura 1. Se indican los números de fallas de la Tabla 1.

possibility. Some faults have been revealed from seismic profiles (Rodríguez-Fernández and Sanz de Galdeano, 2006), such as the Alitaje Fault, parallel to the major Pinos Puente Fault.

Most of the main active faults of the basin are concentrated in the area from Sierra Elvira to Padul, passing through the area of Granada. These have a NW-SE direction and a normal character. Some of the characteristics of these faults are showed in Table 1. The main faults are described below.
The Fargue-Jun Fault dips to the SW, cutting through alluvial rocks of the Alhambra Formation, and is PliocenePleistocene in age. Its scarp, developed in Pleistocene sedimentary rocks, indicates its recent activity.

The Granada Fault also dips to the SW and crosses the city of Granada. Its scarp is preserved only to the $\mathrm{N}$ and $\mathrm{S}$ of the city; it cannot be traced through the urbanised parts of Granada. Upper Pliocene-Pleistocene sediments of the Alhambra Formation are affected by several splays of this fault which produce topographic steps in the NW 


\begin{tabular}{|c|c|c|c|c|c|c|c|c|}
\hline $\begin{array}{l}\text { Number, name } \\
\text { and geometry }\end{array}$ & $\begin{array}{l}\text { Endpoints } \\
\text { (lon./lat.) }\end{array}$ & $\begin{array}{c}l \\
(\mathrm{~km})\end{array}$ & $\begin{array}{c}d^{2} \\
(\mathrm{~km})\end{array}$ & $\delta$ & $\begin{array}{c}v^{3} \\
(\mathrm{~mm} / \mathrm{yr})\end{array}$ & $\begin{array}{l}\text { Maximum } \\
\text { magnitude } \\
\qquad M_{w}, \sigma\end{array}$ & $\begin{array}{l}\text { Reference } \\
\text { earthquake } \\
\qquad M_{W}\end{array}$ & Remarks \\
\hline $\begin{array}{l}\text { 1. N of Sierra } \\
\text { Tejeda, sl-n }\end{array}$ & $\begin{array}{l}394600,4091533 \\
414853,4086868\end{array}$ & 23.1 & $\begin{array}{l}>10 \\
(\mathrm{~g})\end{array}$ & $\begin{array}{c}60^{\circ}-90^{\circ} \\
\mathrm{N}\end{array}$ & $\begin{array}{c}0.125 \\
{[10 \mathrm{Ma}]}\end{array}$ & $\begin{array}{r}\mathbf{6 . 7}, \mathbf{0 . 2}^{\mathrm{a}} \\
>\mathbf{6 . 4 , 0 . 1 ^ { \mathrm { b } }} \\
\quad 6.6,0.7^{\mathrm{a}} \\
>\quad 6.3,0.5^{\mathrm{b}} \\
\quad 6.9,0.2^{\mathrm{c}}\end{array}$ & $>4.9$ & $\begin{array}{l}\text { Evidences of recent motion. Possible re- } \\
\text { sponsible for the } 12 / 25 / 1884 \text { earthquake. }\end{array}$ \\
\hline 2. Granada, $\mathrm{n}$ & $\begin{array}{l}447012,4115895 \\
453693,4104206\end{array}$ & 16.8 & $\begin{array}{l}>10 \\
(\mathrm{~s})\end{array}$ & $\begin{array}{l}60^{\circ} \\
\text { WSW }\end{array}$ & $\begin{array}{c}0.12 \\
{[2.5 \mathrm{Ma}]}\end{array}$ & $\begin{array}{r}6.5,0.7^{\mathrm{a}} \\
>6.3,0.5^{\mathrm{b}} \\
6.7,0.2^{\mathrm{c}}\end{array}$ & $>4.9$ & $\begin{array}{l}\text { This fault has } 300 \mathrm{~m} \text { of throw and af- } \\
\text { fects the Pleistocene deposits. It moved } \\
\text { noticeably since } 0.8 \mathrm{Ma} \text { ago. }\end{array}$ \\
\hline 3. Padul, n & $\begin{array}{l}438150,4105859 \\
448751,4095360\end{array}$ & 15.2 & $\begin{array}{l}>5 \\
(\mathrm{~g})\end{array}$ & $\begin{array}{l}50^{\circ}-60^{\circ} \\
\text { WSW }\end{array}$ & $\begin{array}{c}0.16 \\
{[5 \mathrm{Ma}]} \\
0.35 \\
{[1 \mathrm{Ma}]}\end{array}$ & 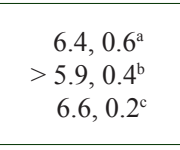 & $>5.3$ & $\begin{array}{l}\text { This fault is spectacular and has very } \\
\text { clear signs of being active. It moves } \\
\text { jointly with the Padul-Dúrcal fault. }\end{array}$ \\
\hline 4. Santa Fe, n & $\begin{array}{l}435398,4117751 \\
442512,4106938\end{array}$ & 13.0 & $\begin{array}{l}>10 \\
(\mathrm{~g})\end{array}$ & $\begin{array}{l}60^{\circ} \\
\mathrm{ENE}\end{array}$ & $\begin{array}{c}0.2 \\
{[5 \mathrm{Ma}]}\end{array}$ & $\begin{array}{r}6.3,0.6^{\mathrm{a}} \\
>6.1,0.4^{\mathrm{b}} \\
6.5,0.2^{\mathrm{c}}\end{array}$ & $>5.2$ & $\begin{array}{l}\text { This fault is inferred from its geomor- } \\
\text { phic features and the different nature of } \\
\text { the materials on both sides. This fault } \\
\text { and its parallel seemingly have notice- } \\
\text { able associated seismicity. }\end{array}$ \\
\hline $\begin{array}{l}\text { 5. Padul - } \\
\text { Dúrcal, n }\end{array}$ & $\begin{array}{l}443269,4100498 \\
452739,4092452\end{array}$ & 13.0 & $\begin{array}{l}>5 \\
(\mathrm{~g})\end{array}$ & $\begin{array}{c}40^{\circ}-60^{\circ} \\
W S W\end{array}$ & $\begin{array}{c}0.2 \\
{[5 \mathrm{Ma}]} \\
0.35 \\
{[1 \mathrm{Ma}]}\end{array}$ & $\begin{array}{r}6.3,0.6^{\mathrm{a}} \\
> \\
5.9,0.4^{\mathrm{b}} \\
\\
6.5,0.2^{\mathrm{c}}\end{array}$ & $>5.3$ & $\begin{array}{l}\text { This fault is spectacular and has very } \\
\text { clear signs of being active. It moves } \\
\text { jointly with the Padul fault. }\end{array}$ \\
\hline 6. Atarfe, $n$ & $\begin{array}{l}434024,4123642 \\
441246,4116488\end{array}$ & 10.3 & $\begin{array}{l}>10 \\
(\mathrm{~g}, \mathrm{~s})\end{array}$ & $\begin{array}{c}60^{\circ} \\
\text { WSW }\end{array}$ & $\begin{array}{c}0.12 \\
{[2.5 \mathrm{Ma}]}\end{array}$ & $\begin{array}{r}6.2,0.6^{\mathrm{a}} \\
>6.0,0.4^{\mathrm{b}} \\
6.5,0.2^{\mathrm{c}} \\
\end{array}$ & $>4.9$ & $\begin{array}{l}\text { This fault presents a large scarp and has } \\
\text { substantial associated low-magnitude } \\
\text { seismicity. }\end{array}$ \\
\hline $\begin{array}{l}\text { 7. El Fargue - } \\
\text { Jun, n }\end{array}$ & $\begin{array}{l}443955,4123348 \\
451532,4114869\end{array}$ & 11.7 & $\begin{array}{c}>10 \\
(\mathrm{~s})\end{array}$ & $\begin{array}{c}60^{\circ} \\
\text { WSW }\end{array}$ & $\begin{array}{c}0.06 \\
{[5 \mathrm{Ma}]}\end{array}$ & $\begin{array}{r}6.3,0.6^{\mathrm{a}} \\
>6.1,0.4^{\mathrm{b}} \\
6.6,0.2^{\mathrm{c}} \\
\end{array}$ & $>4.5$ & $\begin{array}{l}\text { This fault presents clear activity during } \\
\text { the Quaternary. It clearly has associated } \\
\text { seismicity (series of June 4th, 1998). }\end{array}$ \\
\hline $\begin{array}{l}\text { 8. Belicena - } \\
\text { Alhendín, } n\end{array}$ & $\begin{array}{l}437603,4115959 \\
443314,4107265\end{array}$ & 10.4 & $\begin{array}{l}>5 \\
(\mathrm{ss})\end{array}$ & $\begin{array}{l}60^{\circ} \\
\mathrm{ENE}\end{array}$ & $\begin{array}{c}0.2 ? \\
{[5 \mathrm{Ma}]}\end{array}$ & $\begin{array}{r}6.2,0.6^{\mathrm{a}} \\
>5.7,0.4^{\mathrm{b}} \\
{\left[6.4,0.2^{\mathrm{c}}\right]} \\
\end{array}$ & {$[>5.0]$} & $\begin{array}{l}\text { It is known from seismic profiles and is } \\
\text { seemingly associated with many low- } \\
\text { magnitude earthquakes. }\end{array}$ \\
\hline 9. Albuñuelas, $\mathrm{n}$ & $\begin{array}{l}440774,4087091 \\
450029,4085700\end{array}$ & 9.8 & $\begin{array}{l}>5 \\
(\mathrm{~g})\end{array}$ & $\begin{array}{c}40^{\circ}-60^{\circ} \\
\mathrm{N}\end{array}$ & $\begin{array}{c}0.14 \\
{[5 \mathrm{Ma}]}\end{array}$ & $\begin{array}{r}6.2,0.6^{\mathrm{a}} \\
>5.8,0.4^{\mathrm{b}} \\
\quad 6.4,0.2^{\mathrm{c}} \\
\end{array}$ & $>4.8$ & $\begin{array}{l}\text { It affects the upper Miocene and recent } \\
\text { Quaternary deposits. It is, therefore, } \\
\text { active. }\end{array}$ \\
\hline $\begin{array}{l}\text { 10. Pinos } \\
\text { Puente, } \mathrm{n}\end{array}$ & $\begin{array}{l}432879,4124538 \\
438856,4117392\end{array}$ & 9.4 & $\begin{array}{c}>10 \\
(\mathrm{~s})\end{array}$ & $\begin{array}{c}60^{\circ} \\
\text { WSW }\end{array}$ & $\begin{array}{c}0.4 \\
{[5 \mathrm{Ma}]}\end{array}$ & $\begin{array}{r}6.1,0.6^{\mathrm{a}} \\
> \\
6.0,0.4^{\mathrm{b}} \\
\quad 6.3,0.2^{\mathrm{c}}\end{array}$ & $>5.6$ & $\begin{array}{l}\text { This fault has seemingly a great low } \\
\text { magnitude seismicity associated with } \\
\text { it. Its throw is about } 2 \mathrm{~km} \text {. It presents } \\
\text { important scarps. }\end{array}$ \\
\hline 11. Dílar, n & $\begin{array}{l}447397,4106573 \\
452605,4100330\end{array}$ & 8.3 & $\begin{array}{c}>10 \\
(\mathrm{~g})\end{array}$ & $\begin{array}{l}60^{\circ} \\
\mathrm{W}\end{array}$ & $\begin{array}{c}0.16 \\
{[5 \mathrm{Ma}]}\end{array}$ & $\begin{array}{r}6.1,0.6^{\mathrm{a}} \\
>5.9,0.4^{\mathrm{b}} \\
6.3,0.2^{\mathrm{c}} \\
\end{array}$ & $>5.0$ & $\begin{array}{l}\text { This fault is clearly active because it } \\
\text { affects the Pleistocene deposits. }\end{array}$ \\
\hline 12. Alitaje, $n$ & $\begin{array}{l}431371,4124551 \\
435056,4119418\end{array}$ & 6.4 & $\begin{array}{l}>5 \\
(\mathrm{ss})\end{array}$ & $\begin{array}{c}40^{\circ}-60^{\circ} \\
\mathrm{S}\end{array}$ & $\begin{array}{c}0.1 \\
{[5 \mathrm{Ma}]}\end{array}$ & $\begin{array}{r}5.9,0.5^{\mathrm{a}} \\
>5.6,0.4^{\mathrm{b}} \\
\quad 6.2,0.2^{\mathrm{c}}\end{array}$ & $>4.6$ & $\begin{array}{l}\text { This fault is known from seismic } \\
\text { profiles. It affects the Pleistocene-Qua- } \\
\text { ternary deposits, and probably moves } \\
\text { jointly with the Pinos Puente fault. }\end{array}$ \\
\hline $\begin{array}{l}\text { 13. Obéilar- } \\
\text { Pinos Puente, } \\
\text { n-sl }\end{array}$ & $\begin{array}{l}432883,4125093 \\
425068,4123717\end{array}$ & 7.9 & $\begin{array}{l}>10 \\
(\mathrm{ss}, \mathrm{g})\end{array}$ & $\begin{array}{c}60^{\circ}-90^{\circ} \\
\mathrm{S}\end{array}$ & $\begin{array}{c}0.4 \\
{[8 \mathrm{Ma}]}\end{array}$ & $\begin{array}{r}6.0,0.6^{\mathrm{a}} \\
>5.9,0.4^{\mathrm{b}} \\
6.2,0.2^{\mathrm{c}} \\
\mathbf{6 . 2}, \mathbf{0 . 2}^{\mathrm{a}} \\
>\mathbf{5 . 9}, \mathbf{0 . 1}^{\mathrm{b}} \\
\end{array}$ & $>5.5$ & $\begin{array}{l}\text { This fault is deduced by seismic profiles } \\
\text { and also observable in the field. It shows } \\
\text { recent motion. Its throw is of the order } \\
\text { of } 2500 \mathrm{~m} \text { and forms the northern border } \\
\text { of a very subsident sector. }\end{array}$ \\
\hline 14. Huenes, sl-n & $\begin{array}{l}455234,4109745 \\
452993,4106207\end{array}$ & 5.0 & $\begin{array}{l}>10 \\
(\mathrm{~g})\end{array}$ & $\begin{array}{c}60^{\circ}-70^{\circ} \\
W\end{array}$ & $\begin{array}{c}0.25 \\
{[0.4 \mathrm{Ma}]}\end{array}$ & 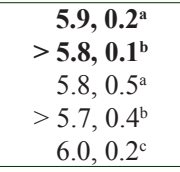 & $>5.3$ & $\begin{array}{l}\text { This fault affects middle Pleistocene } \\
\text { sediments and presents very recent and } \\
\text { well-preserved scarps. The horizontal } \\
\text { displacement has not been calculated. }\end{array}$ \\
\hline \multicolumn{9}{|c|}{ 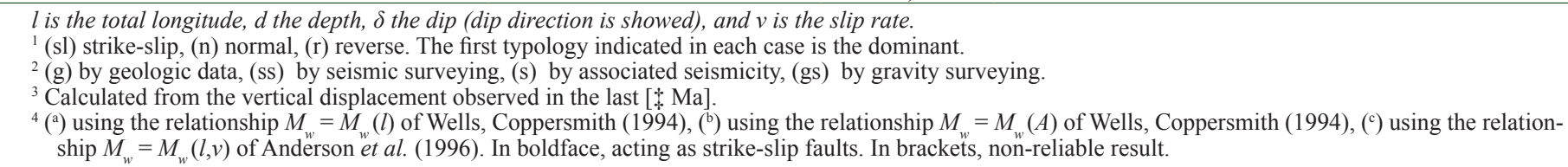 } \\
\hline
\end{tabular}

Table 1.- Main active faults in the Granada Basin.

Tabla 1.- Principales fallas activas en la cuenca de Granada. 
part of the city (Azañon et al., 2004). There is a prominent low-magnitude activity of seismicity along its length and is associated with a wider fault zone, but there is no evidence of the occurrence of large earthquakes associated with this fault.

The Sierra Elvira-Dilar Fault. This name refers to the linkage of the faults of Pinos Puente, Atarfe and Dílar (Fig. 2) indicated in Table 1. If this association is valid, they can be considered different segments of a single fault. In total, the fault has a length of approximately 33 $\mathrm{km}$ and dips to the SW. Particularly, near the ends of the fault there is good evidence of recent deformations. A significant number of low-magnitude earthquakes can be attributed to this fault, specially in its northern part. Probably this fault was responsible for the $1956\left(m_{D} 5.0\right) \mathrm{NW}$ Purchil earthquake, which was felt with intensity VIII in the epicentral area, also situated in the northern part.

The Alhendin-Santa Fe Fault. This fault comprises the Belicena-Alhendín and Santa Fe faults which are described as separated faults in Table 1. These faults dips to the NE and can be considered as a conjugate fault set to the Sierra Elvira-Dilar Fault. Although the scarp of the fault, particularly in its northern part, is not well preserved, both seismic profiles (Rodríguez Fernández and Sanz de Galdeano, 2006) and gravimetric data show a larger throw than observed in field. Some low-magnitude earthquakes could be also associated with this system.

In the area of Padul, two major faults, the Padul and Padul-Dúrcal Faults, are parallel and probably converge in depth, and could be considered as different splays of a single fault. They are separated in Table 1, and also here.

The Padul Fault. This fault dips to the SW and separates the metamorphic basement of the Internal Zone from upper Miocene and Plio-Quaternary sediments. This fault has very well-expressed triangular facets, fault scarps, and recent peat layers are tilted towards the fault (Lhénaff, 1965; Estévez and Sanz de Galdeano, 1983; Riley and Moore, 1993; Calvache et al., 1997, Sanz de Galdeano and López-Garrido, 1999).

The Padul-Dúrcal Fault. It is also called the Nigüelas Fault, being parallel to the Padul Fault. Santanach et al. (1980) estimated a large throw even reaching $800 \mathrm{~m}$ or more from the late Miocene. Both faults display a spectacular geomorphology (Fig. 5), and are among some of the best examples of active tectonics in the Betics (for details of displacement rates, etc., see Table 1). However, seismicity associated with these faults is absent at present (Alfaro et al., 2001; Ruiz et al., 2002).

The North of Sierra Tejeda Fault is situated in the south border of the Granada Basin. It is probably the largest E-W fault of the basin. It forms the southern border of the basin and has been associated with strong subsidence since the Messinian. It was probably responsible for the 1884 Andalusian earthquake, one of the most destructive earthquakes known in the Betics. This fault continues to the west in the area of Zafarraya, and in some cases is named after it (Reicherter et al., 2003, Galindo-Zaldívar et al., 2003). During the early and middle Miocene, it moved mainly as a dextral strike-slip fault, but from the late Miocene its movement has been predominantly vertical, in some places on the order of a thousand metres, forming the impressive wall of the Tejeda and Almijara Sierras.

To the east, the Sierra Tejeda Fault continues as the $\mathrm{Al}$ buñuelas Fault, which locally exposes some Quaternary sediments in its scarp. Moreover, near the south of the basin lie other E-W faults, in some cases possibly active.

The E-W striking Obéilar-Pinos Puente Fault marks the northern limit of the Pinos Puente and other NNWSSE faults. Indeed, it corresponds to a segment of the former Cádiz-Alicante Fault (Sanz de Galdeano, 1983 and 2008), and contributes to the formation of the depocentre of the area of Pinos-Puente and Santa Fe.

The Huenes Fault is the only NNE-SSW fault cited here. It is situated to the SE of Granada and is part of the western limit of Sierra Nevada. The recent aspect of its scarp is notable, and the striae of the scarp indicate normal-sinistral displacements. Southwards, this fault is linked into the Granada Fault.

In addition, low-angle faults in Sierra Nevada affect the contact between the tectonic units of the Internal Zone. The displacement of these faults generally agrees with the direction of tension (NE-SW), the hanging blocks in most cases moving to the SW. These low-angle normal faults may extend below the Granada Basin and its reactivation interacting with the high-angle fault sets may be responsible for part of the seismicity.

\section{Active faults in the Guadix-Baza Basin}

In this basin we have identified 35 faults affecting late Miocene to Quaternary sediments. Some of them offer no clear evidence of deformation of the more recent Quaternary sediments or are too short in length to be included in this study. For example, the Tíscar strike-slip Fault (Foucault, 1971; Sanz de Galdeano et al., 2006) or the Guadiana Menor and Alcóntar faults (Fig. 3) deform rocks of late Miocene, Pliocene or early Pleistocene age, but they lack clear evidence of deformation of the more recent Quaternary sediments that fill the Guadix-Baza Basin. Another fault revealed from a gravity survey is the Benamaurel Fault (Sanz de Galdeano et al., 2007), which 


\begin{tabular}{|c|c|c|c|c|c|c|c|c|}
\hline $\begin{array}{l}\text { Number, name } \\
\text { and geometry }\end{array}$ & $\begin{array}{l}\text { Endpoints } \\
\text { (lon./lat.) }\end{array}$ & $\begin{array}{c}l \\
(\mathrm{~km})\end{array}$ & $\begin{array}{c}d^{2} \\
(\mathrm{~km})\end{array}$ & $\delta$ & $\begin{array}{c}v^{3} \\
(\mathrm{~mm} / \mathrm{yr})\end{array}$ & $\begin{array}{l}\text { Maximum } \\
\text { magnitude } \\
\qquad M_{w}, \sigma\end{array}$ & $\begin{array}{c}\text { Reference } \\
\text { earthquake } \\
M_{W}\end{array}$ & Remarks \\
\hline 1. Galera, n-sl & $\begin{array}{l}545161,4183859 \\
527690,4169581\end{array}$ & 23.0 & $\begin{array}{l}>5 \\
(g, s)\end{array}$ & $\begin{array}{l}70^{\circ} \\
\mathrm{NW}\end{array}$ & $\begin{array}{c}0.28 \\
{[0.5 \mathrm{Ma}]}\end{array}$ & $\begin{array}{c}6.6,0.7^{\mathrm{a}} \\
>6.0,0.4^{\mathrm{b}} \\
6.8,0.2^{\mathrm{c}} \\
\mathbf{6 . 7}, \mathbf{0 . 2}^{\mathrm{a}} \\
>\mathbf{6 . 1}, \mathbf{0 . 1}^{\mathrm{b}}\end{array}$ & $>5.1$ & $\begin{array}{l}\text { Potentially responsible for the June } \\
9,1964\left(m_{b L g} 4.8, \text { VIII }\right) \text { SW Galera } \\
\text { earthquake. It shows clear normal and } \\
\text { sinistral fault features. }\end{array}$ \\
\hline
\end{tabular}

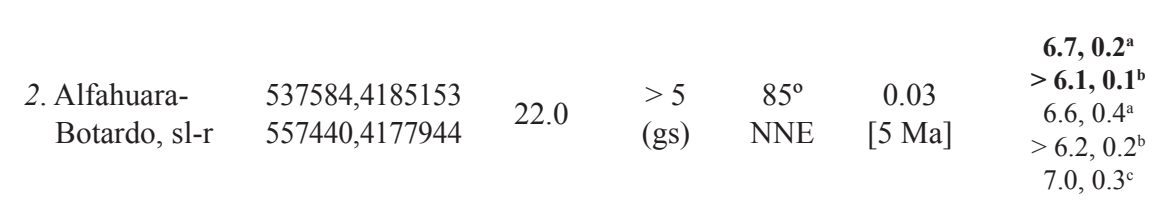

This has been an active fault since the Late Miocene but not always with a clearly visible fault plane (mostly hidden). Considering its seemingly
associated seismicity, it appears more active in its western section. It is potentially responsible for the March 21, $1973\left(m_{b L g} 4.0\right)$ NE Orce earthquake. The magnitude of its lateral (dextral) motion is not known.

Potentially responsible for the September 30, 1531 (macroseismic $M_{S}$ 6.0,

\begin{tabular}{|c|c|c|c|c|c|c|c|c|}
\hline 3. Baza, n & $\begin{array}{l}516671,4167332 \\
530022,4134197\end{array}$ & 37.1 & $\begin{array}{c}>10 \\
(\mathrm{~g}, \mathrm{gs}, \mathrm{ss})\end{array}$ & $\begin{array}{c}65^{\circ} \\
\mathrm{E}\end{array}$ & $\begin{array}{c}0.22-0.37 \\
{[5 \mathrm{Ma}]}\end{array}$ & $\begin{array}{c}6.9,0.7^{\mathrm{a}} \\
>6.6,0.5^{\mathrm{b}} \\
7.0,0.2^{\mathrm{c}}\end{array}$ & $>5.4$ & $\begin{array}{l}\text { VIII-IX) Baza earthquake. It induced a } \\
\text { significant sinking in the eastern side. } \\
\text { Considering its seemingly associated } \\
\text { seismicity, it appears to be more active } \\
\text { in its northern part. }\end{array}$ \\
\hline
\end{tabular}

\begin{tabular}{|c|c|c|c|c|c|c|c|c|}
\hline $\begin{array}{l}\text { 4. Graena } \\
\text { Lugros, n-sl }\end{array}$ & $\begin{array}{l}480861,4130061 \\
483954,4126171\end{array}$ & 10.4 & $\begin{array}{l}>10 \\
(g, s)\end{array}$ & $\begin{array}{l}70^{\circ} \\
\mathrm{NE}\end{array}$ & $\begin{array}{c}0.06 \\
{[8 \mathrm{Ma}]}\end{array}$ & $\begin{array}{c}6.2,0.6^{\mathrm{a}} \\
>6.0,0.4^{\mathrm{b}} \\
6.5,0.2^{\mathrm{c}} \\
\mathbf{6 . 3 , 0 . 2 ^ { \mathrm { a } }} \\
>\mathbf{6 . 1}, \mathbf{0 . 1}^{\mathrm{b}}\end{array}$ & $>4.4$ & $\begin{array}{l}\text { Movements during the Miocene-Pleis- } \\
\text { tocene are evident, but not recent ones. } \\
\text { The displacement has a dextral compo- } \\
\text { nent. It has associated low-magnitude } \\
\text { earthquakes. }\end{array}$ \\
\hline
\end{tabular}

\begin{tabular}{|c|c|c|c|c|c|c|c|c|}
\hline $\begin{array}{l}\text { 5. Zambo- } \\
\text { rino }(\mathrm{a}), \mathrm{n}\end{array}$ & $\begin{array}{l}482583,4148473 \\
496896,4123938\end{array}$ & 25.0 & $\begin{array}{l}>5 \\
(\mathrm{~g})\end{array}$ & $\begin{array}{l}65^{\circ} \\
\text { SW }\end{array}$ & $\begin{array}{c}0.10 \\
{[0.5 \mathrm{Ma}]}\end{array}$ & $\begin{array}{c}6.7,0.7^{\mathrm{a}} \\
>6.1,0.4^{\mathrm{b}} \\
6.9,0.3^{\mathrm{c}}\end{array}$ & $>4.6$ & $\begin{array}{l}\text { It forms morphologic scarps affecting } \\
\text { the glacis of the basin. }\end{array}$ \\
\hline
\end{tabular}

\begin{tabular}{|c|c|c|c|c|c|c|c|c|}
\hline $\begin{array}{l}\text { 6. East of } \\
\text { Guadix, } \mathrm{n}\end{array}$ & $\begin{array}{l}486185,4135153 \\
492908,4126713\end{array}$ & 10.8 & $\begin{array}{c}\sim 5 \\
(\mathrm{~g}, \mathrm{~s})\end{array}$ & $90^{\circ}$ & $\begin{array}{c}0.10 \\
{[0.5 \mathrm{Ma}]}\end{array}$ & $\begin{array}{l}6.2,0.6^{\mathrm{a}} \\
5.7,0.4^{\mathrm{b}} \\
6.5,0.2^{\mathrm{c}}\end{array}$ & $\sim 4.5$ & $\begin{array}{l}\text { In the field it appears as great vertical } \\
\text { joints, partially eroded by the glacis of } \\
\text { the Guadix-Baza Basin. There is some } \\
\text { seismicity seemingly related. Linked } \\
\text { geological features are scarce. }\end{array}$ \\
\hline
\end{tabular}

\begin{tabular}{|c|c|c|c|c|c|c|}
\hline 7. N of Cúllar, n? & $\begin{array}{l}541781,4173412 \\
535638,4167059\end{array}$ & 8.9 & $\begin{array}{l}\sim 5 \\
(\mathrm{~s})\end{array}$ & - & {$\left[6.1,0.6^{\mathrm{a}}\right]$} & $\begin{array}{l}\text { Inferred from seismicity data, not from } \\
\text { geological data. Its line and features } \\
\text { should be taken with caution. }\end{array}$ \\
\hline
\end{tabular}

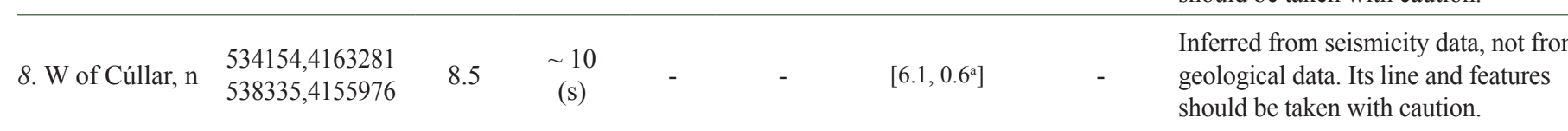

\begin{tabular}{|c|c|c|c|c|c|c|c|}
\hline 9. Benamaurel, $\mathrm{n}$ & $\begin{array}{l}524014,4159917 \\
532378,4143303\end{array}$ & 18.7 & $\begin{array}{l}>10 \\
(\mathrm{gs}, \mathrm{s})\end{array}$ & $\begin{array}{l}60^{\circ} \\
\text { SW }\end{array}$ & $\begin{array}{c}0.20 \\
{[5 \mathrm{Ma}]}\end{array}$ & $\begin{array}{c}6.5,0.7^{\mathrm{a}} \\
>6.3,0.5^{\mathrm{b}} \\
6.7,0.2^{\mathrm{c}}\end{array}$ & $>5.2$ \\
\hline
\end{tabular}

Inferred from gravity surveying and seismicity data. It is antithetic of the Baza fault set. It is potentially responsible for the November 16, $2003\left(m_{b L g}\right.$ 4.1, IV) SW Benamaurel earthquake.

\footnotetext{
$l$ is the total longitude, $d$ the depth, $\delta$ the dip (dip direction is showed), and $v$ is the slip rate.

${ }^{1}$ (sl) strike-slip, (n) normal, (r) reverse. The first typology indicated in each case is the dominant.

${ }^{2}$ (g) by geologic data, (ss) by seismic surveying, (s) by associated seismicity, (gs) by gravity surveying.

${ }^{3}$ Calculated from the vertical displacement observed in the last $[\$ \mathrm{Ma}]$.

${ }^{4}\left({ }^{\mathrm{a}}\right)$ using the relationship $M_{w}=M_{w}(l)$ of Wells and Coppersmith $(1994),\left(^{b}\right)$ using the relationship $M_{w}=M_{w}(A)$ of Wells and Coppersmith (1994), $\left({ }^{c}\right)$ using the relationship $M_{w}=M_{w}(l, v)$ of Anderson et al. (1996). In boldface, acting as strike-slip faults. In brackets, non-reliable result.

${ }^{5}$ For a return period of 475 years and acting as normal faults. In brackets, non-reliable result.
}

Table 2. Main active faults in the Guadix-Baza Basin.

Tabla 2. Principales fallas activas en la cuenca de Guadix-Baza. 
has no surface-deformation features associated with it. In addition, some faults have been inferred exclusively from seismic data (e.g., N, NE, E and W Cúllar faults, see Fig. $3)$. These faults have some associated seismic activity, such as the May 14, $1979\left(m_{b L g} 4.2\right)$ E Cúllar earthquake. Finally, other faults show recent activity, but their length is shorter than $10 \mathrm{~km}$ (Hijate, W of the Negratín, SW of the Negratín and Alicún faults, see Fig. 3).

As in the Granada Basin, in the Guadix-Baza Basin only the main active faults (length $>10 \mathrm{~km}$ ) have been considered. They must exhibit associated seismicity or evidence of associated deformation of Middle to Late Pleistocene rocks (approximately the last $500 \mathrm{ka}$ ). These faults, which deform the glacis of the Guadix-Baza Basin, are the following (Table 2).

The Galera Fault zone (García Tortosa et al. 2007, 2011) is a left-lateral normal fault, which is $23 \mathrm{~km}$ long and strikes $\mathrm{N} 48^{\circ} \mathrm{E}$ (Fig. 3). The fault zone is $1.5 \mathrm{~km}$ wide with several parallel splays dipping NW between $40^{\circ}$ and $60^{\circ}$, although vertical dips have also been noted locally. The more common pitch of the striae corresponds to approximately $40^{\circ} \mathrm{SW}$, which implies sinistral-normal movement. This fault displaces the glacis about $50 \mathrm{~m}$ in its central segment. From the displacement of the glacis, the mean vertical slip rate ranges between 0.08 and 0.24 $\mathrm{mm} /$ year. Most probably, it caused the June 9, $1964\left(m_{b L g}\right.$ 4.8) SW Galera earthquake (Fig. 4).

The Baza Fault zone (Alfaro et al., 2008; García Tortosa et al., 2008a, 2011) is a $37 \mathrm{~km}$ long normal fault (Figs. 3 and 6). The fault strikes NW-SE in its southern segment and N-S in its northern segment, and its dip ranges between $45^{\circ}$ and $65^{\circ}$ to the east. Within the broader fault zone, there are several roughly parallel splays, more numerous in the southern segment, that converge towards the north. The striations visible on different surfaces indicate purely normal movements. The fault displaces the glacis surface of the basin about $100 \mathrm{~m}$. Part of this throw could be induced by the isostatic rebound linked to the differential erosion between the two subbasins (Fernández-Ibáñez et al., 2010). From the displacement of the glacis, the mean vertical slip rate ranges between 0.17 $-0.49 \mathrm{~mm} / \mathrm{yr}$. The longer term vertical displacement has led to the development of a $30 \mathrm{~km}$ long mountain front. Alfaro et al. (2008), taking into account the total throw of the fault from the late Miocene (ranging from 2000 to $3000 \mathrm{~m}$ ) and the dip (between 45 and $60^{\circ}$ ), deduced a vertical slip rate of $0.22-0.37 \mathrm{~mm} / \mathrm{yr}$.

This fault, the largest in the basin, was probably responsible for the 1531 Baza earthquake (Fig. 4), the most significant shock recorded in the historical seismic catalogue of the area. Considering its associated seismicity, the Baza Fault seems to be more active in its northern part.

The Solana de Zamborino Fault zone (García Tortosa et al., 2008b, 2011) is a SW-dipping, NNW-SSE striking normal fault zone, of over $25 \mathrm{~km}$ length (Fig. 3). It has a wide fault zone, similar to the Baza Fault, with several splays that produce small topographic escarpments that in several sectors have been eroded. The southern splay has low-magnitude earthquakes associated with it. Like the Baza and Galera Faults, the Solana del Zamborino Fault zone cuts Pliocene and Quaternary sediments, displacing the glacis about $50 \mathrm{~m}$. Using this value, the late Quaternary vertical slip rate ranges between $0.08-0.24$ $\mathrm{mm} / \mathrm{yr}$.

The Graena-Lugros Fault zone (Fig. 3) consists of several NW-SE striking normal faults with associated hot springs. This fault zone developed at the contact between the basement rocks of Sierra Nevada, belonging to the Internal Zone, and the sediments of the Guadix-Baza Basin. These SE-dipping faults, each of them around $10 \mathrm{~km}$ long, produce metric to decametric vertical displacements in Pleistocene fluvial rocks and an accumulated displacement of around $40 \mathrm{~m}$ across the glacis. Using this value, the late Quaternary vertical slip rate ranges between 0.07 - $0.19 \mathrm{~mm} / \mathrm{yr}$. Several minor earthquakes are located in the graben of the Zamborino and Graena normal Fault.

The Alfahuara-Botardo Fault (Sanz de Galdeano et al., 2007; García Tortosa et al., 2011) is a dextral-slip fault with a WNW- ESE strike (Fig. 3). This fault is associated with an anticline structure that produces a $\mathrm{N} 120^{\circ} \mathrm{E}$ elongated structural high of more than $20 \mathrm{~km}$ length. This is a growth fold affecting upper Miocene to Pleistocene rocks. Several travertines, some noticeable local silicifications, and discontinuous small faults could be related to a blind fault. This structure probably also displaces the glacis of the basin. It was probably the fault that caused the March $21,1973\left(m_{b L g} 4.0\right)$ NE Orce earthquake. Due to a higher level of background seismicity associated with its western section near Huéscar (Fig. 3), in the junction with the Galera Fault, we consider this part to be the most active.

\section{Seismic potential of the study area}

The computed maximum magnitudes that each fault is able to generate can be initially considered to be an estimation of the seismic potential for each active fault and therefore, for the whole basin. To estimate these values, considering that in most cases there are no historical earthquakes associated with specific faults, we used different relationships proposed by several authors between the maximum magnitude and the length or the surface of 


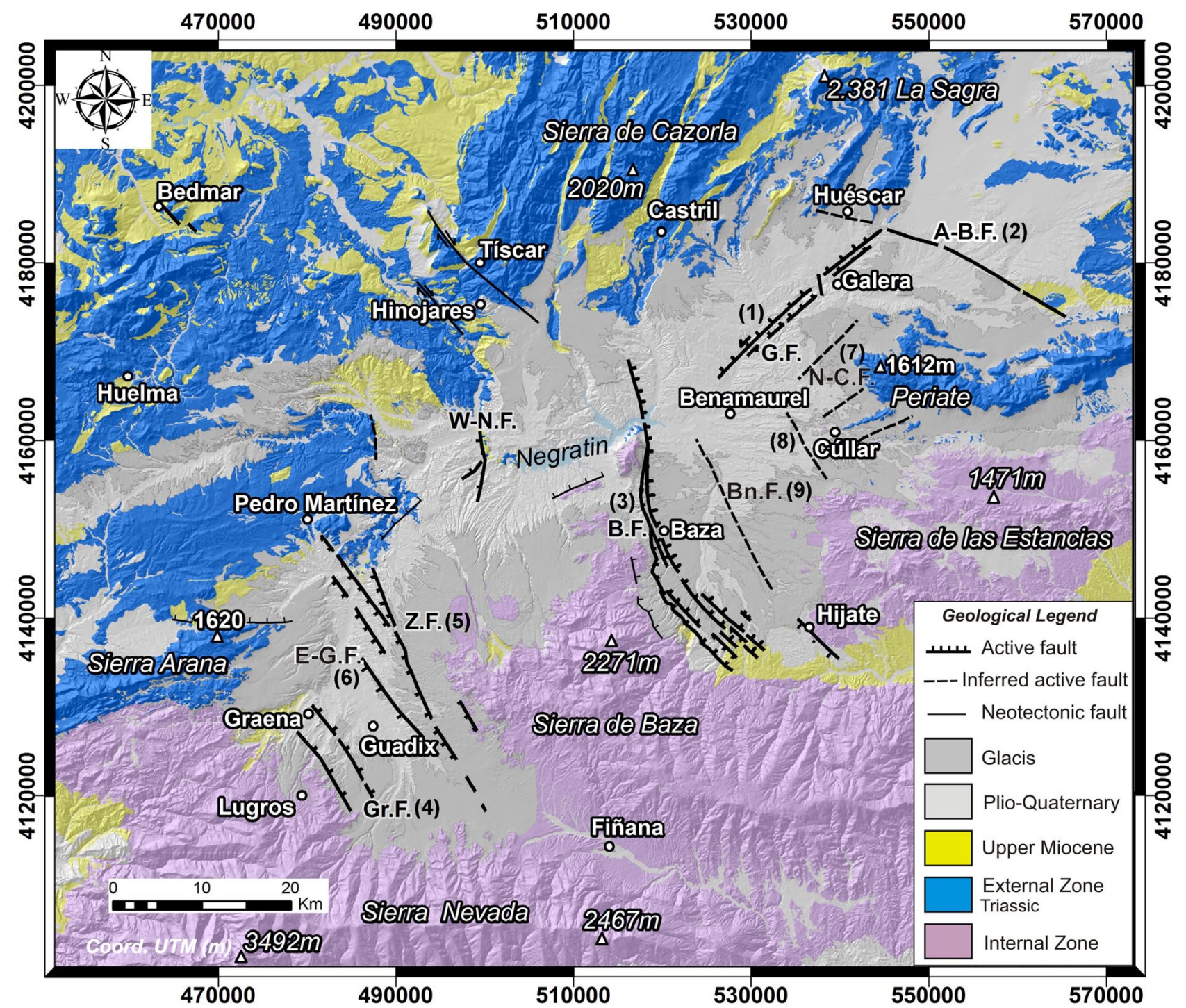

Fig. 3. Simplified geologic map of the Guadix-Baza Basin, showing the main structures. B.F.: Baza Fault zone; G.F.: Galera Fault zone; Gr.F.: Graena Fault zone; Z.F.: Solana del Zamborino Fault zone; A-B.F. Alfahuara-Botardo Fault zone; E-G. F.: E-Guadix Fault; W-N.F.: W-Negratín Fault; B.F.: Benamaurel Fault; N-C. F.: N-Cúllar Fault. Its position is marked on Figure 1. Fault numbers in Table 2 are indicated.

Fig. 3. Mapa geológico simplificado de la cuenca de Guadix-Baza, que muestra las principales estructuras. B.F.: zona de falla de Baza; G.F.: zona de falla de Galera; Gr.F.: zona de falla de Graena; Z.F.: zona de falla del Zamborino; A-B.F. zona de falla de AlfahuaraBotardo; E-G. F.: falla del E de Guadix; W-N.F.: falla del W del Negratín; B.F.: falla de Benamaurel; N-C. F.: falla del N de Cúllar. La posición del mapa se señala en la figura 1. Los números corresponden a las fallas de la Tabla 2.

the fault (Wells and Coppersmith, 1994). Moreover, the slip rates were also included in the estimation of the maximum magnitude, as proposed in other works (Anderson et al., 1996). Thus, we have computed several values that enable us to verify the consistency of the results.

Another informative variable in seismic potential studies proposed by the authors of this work is the so-called reference earthquake, which in fact is more critical than the previously quoted expected maximum magnitude. It is a probabilistic value considered in the Joyner and Fumal (1985) approach to compute the seismic hazard generated by a fault. From the mean slip rate of a certain fault, given a return period, and presuming that the observed fault displacement is fully seismic, the Joyner and Fumal (1985) approach considers that the fault displacement is due to two identical earthquakes. That is, given a certain return period, the method considers that for a given time interval, the fault generates two identical earthquakes that cause the total displacement detected. A clear advantage of this approach is that, as demonstrated by the authors in a previous work (Peláez et al., 2003) using a sensitivity analysis of results, the individual vari- 


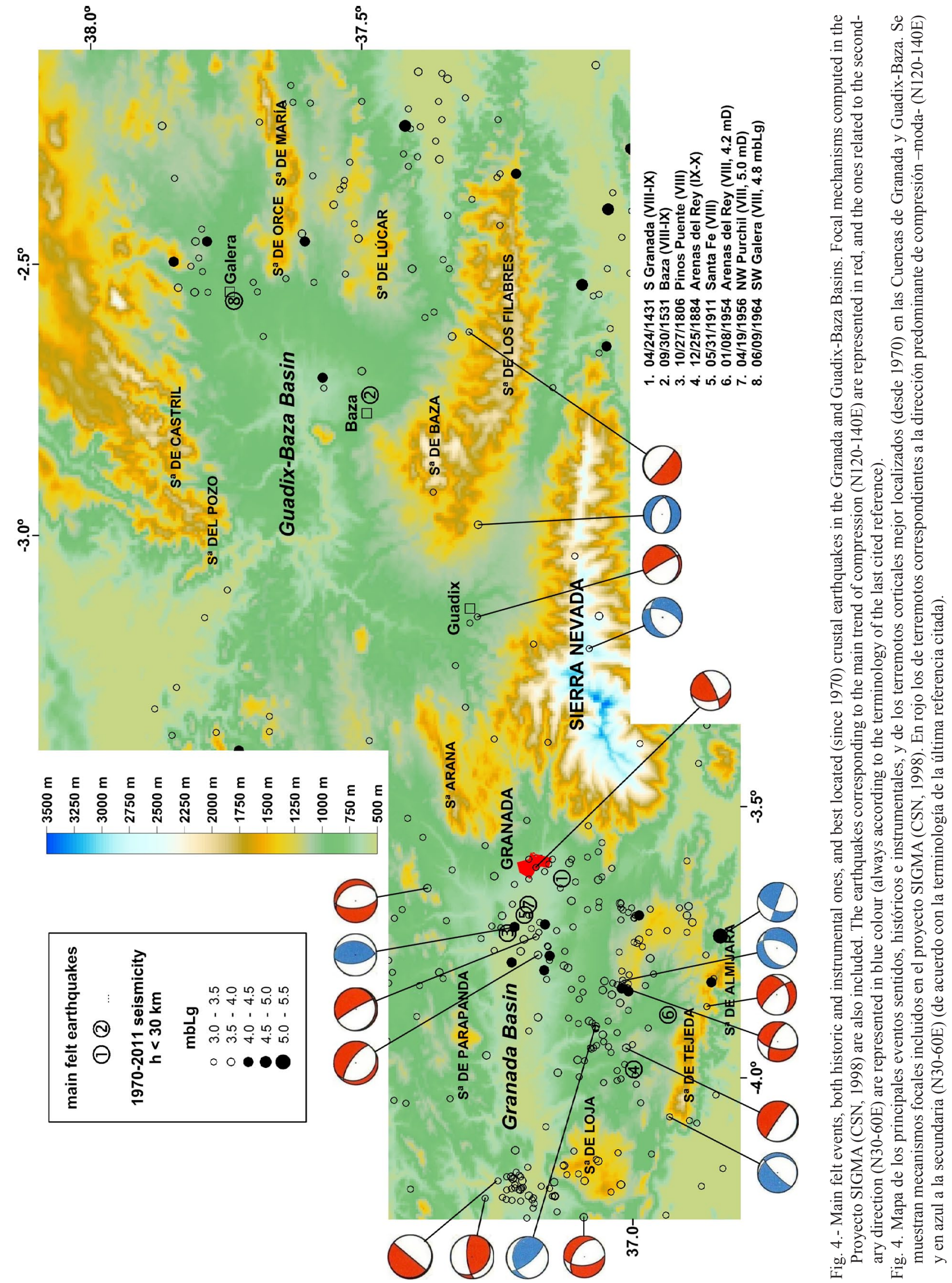


ation of the different analytical parameters is not key in the final result.

This approach considers, as noted above, that for seismic hazard studies, in a probabilistic context, the earthquake sequence of a fault can be replaced by a simulated sequence of two earthquakes in the requested return period. The choice of the return period must be useful to make probabilistic estimates of ground motions corresponding to probability levels of interest, as for example in seismic engineering studies. These two equal shocks, called reference earthquakes, must explain the total slip generated by the fault in such a time interval. Seismic moment for each reference earthquake is given by (Joyner and Fumal, 1985)

$$
\mathrm{M}_{0 \text { ref. earthq. }} \cong \frac{\mu}{\alpha}\left(\frac{\mathrm{T}}{2} \mathrm{v}\right)^{2} \mathrm{w}
$$

Where $\mu$ is the rigidity modulus, $T$ the considered return period, $v$ the slip rate, $w$ the fault width, computed from depth and dip, and $\alpha$ an empirical parameter relating the length of rupture and the displacement observed at surface. The moment magnitude is computed from the assessed seismic moment by using the known Hanks and Kanamori (1979) relationship.

Tables 1 and 2, showing active faults in the Granada and Guadix-Baza Basins, include estimated maximum magnitudes. Moreover, estimated reference earthquakes are shown for a return period of 475 years, i.e. for a $10 \%$ probability of exceedance in 50 years.

In the Granada Basin, the maximum magnitude to be expected is on the order of $M_{w} 6.9$. This value is for the $\mathrm{N}$ of Sierra Tejeda Fault, which was probably the fault that generated the 1884 Andalusian earthquake. Based on their lengths, several faults not included in Table 1, could generate earthquakes with estimated magnitudes higher than $M_{w} 6.0$, though it seems unlikely because they do not present clear Quaternary displacements.

In the NE sector of the Granada Basin, we have assumed that several segments are joined in single and longer fault zones (Alhendín-Belicena and Santa Fe are segments of the Alhendín-Santa Fe Fault, and Dílar, Atarfe and Pinos Puente are segments of the Sierra Elvira-Dílar Fault). For this study, we have estimated the seismic potential for each independent segment.

In the Guadix-Baza Basin, values on the order of $M_{w}$ 6.9 have also been obtained for the Baza Fault when using the relationship by Wells and Coppersmith (1994) between the moment magnitude and the rupture length. This is the most active fault in this region, considering not only the observed displacement among fault blocks but also from the computed mean maximum magnitude.
Therefore, it can be considered to be the fault with the greatest seismic potential in the region. Considering their lengths as rupture lengths, mapped active faults in this region are able to generate earthquakes with magnitudes in the range $M_{w}$ 5.4-6.9. Considering also its mean vertical slip rate from the Anderson et al. (1996) relationships, they could cause earthquakes in the range $M_{w}$ 5.8-7.0.

\section{Conclusions}

The Granada and Guadix-Baza Basins are two of the most active areas of the Iberian Peninsula. Tectonically, both basins are characterized primarily by notable NWSE to NNW-SSE active normal faults which accommodate the present ENE-WSW extension. In the Granada Basin, most of these faults develop from Sierra Elvira (to the north of Granada) to the SSE, reaching the western border of Sierra Nevada and shaping part of its SW border in the Padul-Dúrcal graben. In the Guadix-Baza Basin, the Baza, Zamborino and Graena-Lugros are the most notable NW-SE normal faults.

In addition to these faults, important E-W faults in the Granada Basin include the N of Sierra Tejeda Fault, continued in the Albuñuelas Fault. In the area of Sierra Elvira, the Obéilar-Pinos Puente Fault constitute the northern limit of the NNW-SSE faults. Also, in both basins, active faults with other strike directions include the Huenes Fault (striking NE-SW), the NE-striking Galera Fault and the WNW- striking Alfahuara Fault, both in the GuadixBaza Basin. Geologic and geomorphic markers of different ages indicate that slip rates of these active faults vary between $0.06-0.5 \mathrm{~mm} / \mathrm{yr}$.

Seismically, the two basins show different behaviours. In the Granada Basin, seismicity is dispersed, and in many cases not related to known active faults, with the exception of the more energetic earthquakes. Moreover, a significant seismicity rate of low-magnitude events can be observed.

The background seismicity shows that, apart from the currently known active faults in the basin, there are others with characteristics and locations that have not yet been determined. On the contrary, in the Guadix-Baza Basin, earthquakes are clearly related to the main active faults, in this case, with a lower seismicity rate.

The faults with the greatest seismic potential, and thus implying the most serious seismic hazard, are the North of Sierra Tejeda Fault in the Granada Basin and the Baza Fault in the Guadix-Baza Basin. The probably caused the 1884 Andalusian and the 1531 Baza earthquakes, respectively. Their expected maximum earthquakes are the larg- 


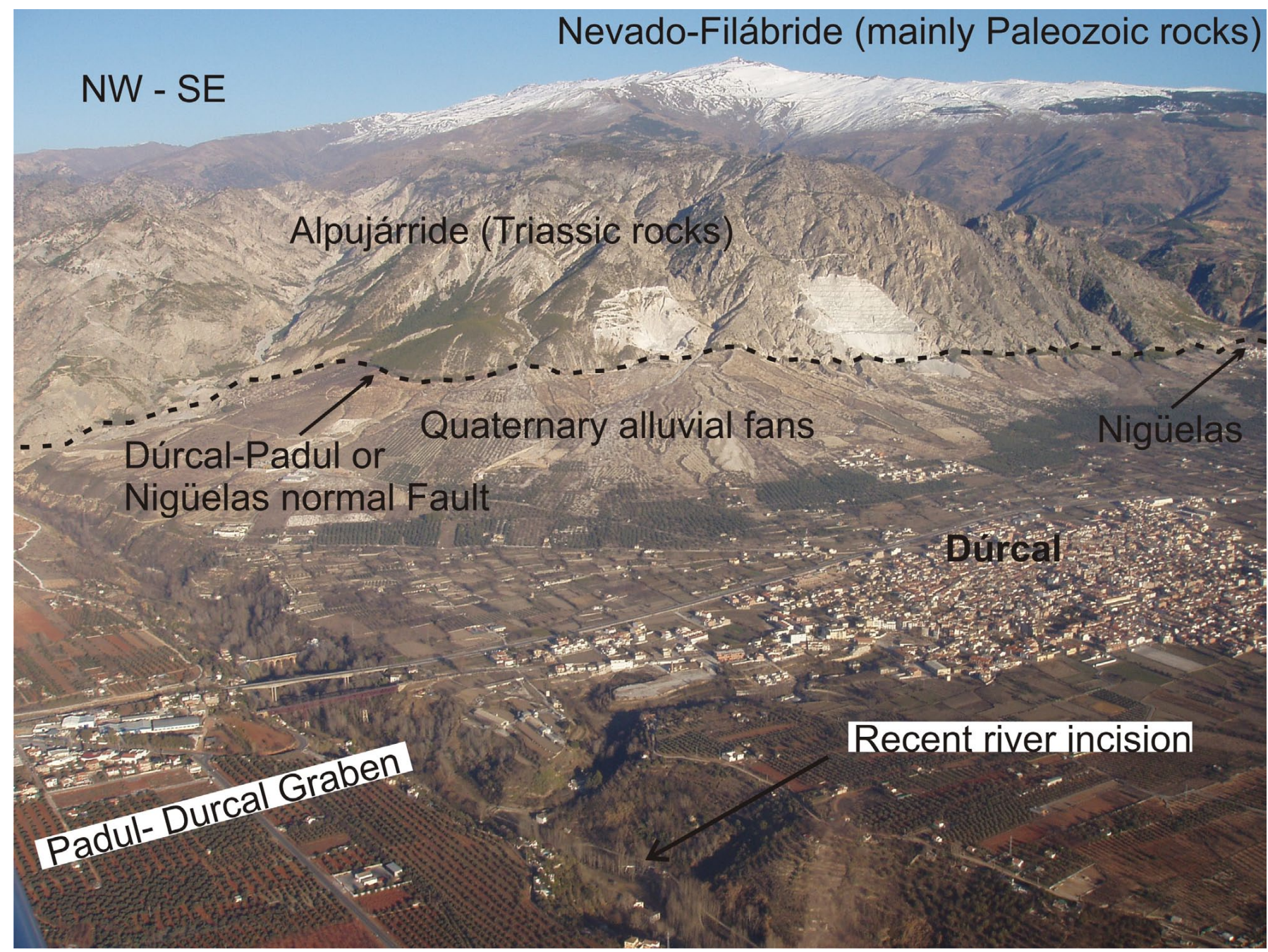

Fig. 5. View of the southern part of the Padul-Dúrcal Fault. Its throw reaches nearly $1000 \mathrm{~m}$ in some places. Photo by J. Sanz de Galdeano.

Fig. 5.- Vista de la parte meridional de la falla del Padul-Dúrcal. Su salto vertical es de casi 1000 m en algunos puntos. Foto de J. Sanz de Galdeano.

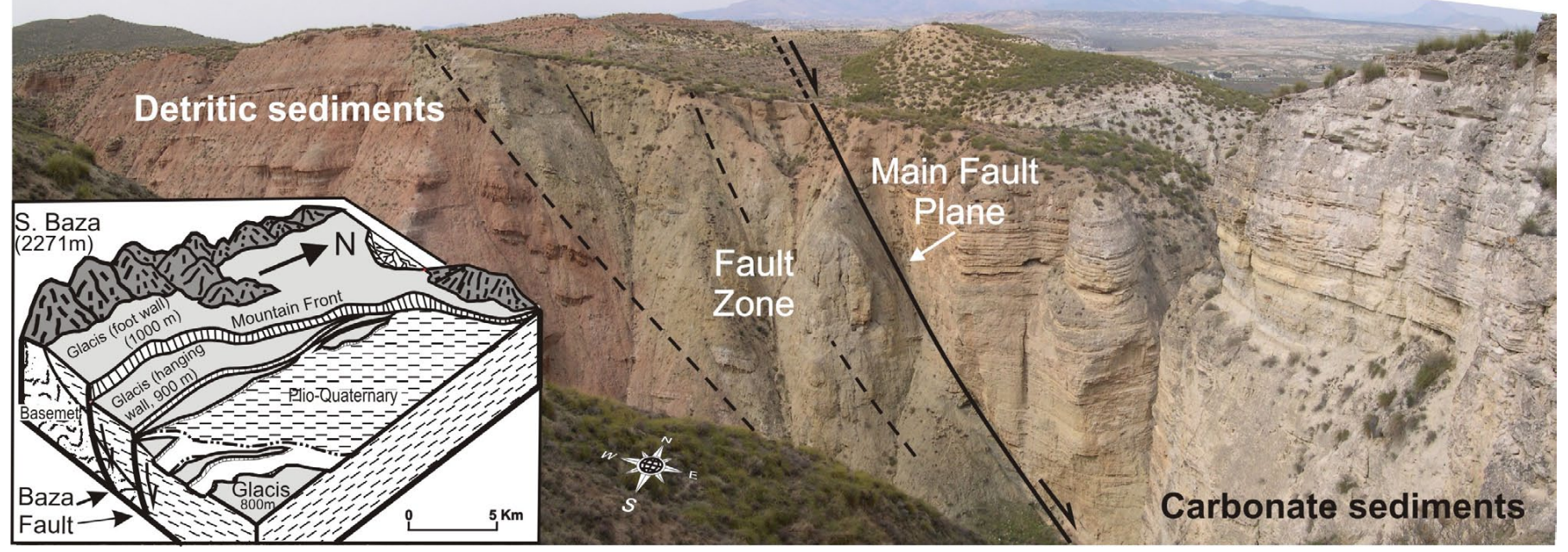

Fig. 6.- Detail of the Baza Fault zone, including a 3-D tectonic sketch of the deformation. The photo is located near the northern part of the fault. Fig. 6.- Detalle de la zona de falla de Baza, incluyendo un esquema tectónico tridimensional de la deformación. La foto se localiza cerca de la parte norte de la falla. 
est in their respective basins.

The appraised seismic potential in terms of the expected maximum magnitude shows that moderate to strong earthquakes, i.e. earthquakes in the range $M_{w} 6.0-7.0$, could be generated if the main faults mentioned above (particularly the Baza Fault) broke along their length or surface. In probabilistic terms, for a return period of 475 years, moderate earthquakes (M 5.0-6.0) could have their origin in the Baza, Galera and Benamaurel Faults, and minor to moderate earthquakes (M 4.0-5.0) could be generated by the most of the other active faults in the region. In any case, this region must be considered as a moderate seismic-hazard area.

\section{Acknowledgements}

This work has been financed through projects TOPOIBERIA CONSOLIDER-INGENIO (CSD2006-00041), CGL2010-21048, CGL-2011-29920, CGL201130153-C02-02, P09-RNM-5388 and the Junta de Andalucía groups RNM 370, RNM148 and RNM325. We thank Dr. Robert Langridge for the very positive proofreading of the manuscript.

\section{References}

Alfaro, P., Galindo-Zaldívar, J., Jabaloy, A., López-Garrido, A.C., Sanz de Galdeano, C. (2001): Evidence for the activity and paleoseismicity of the Padul fault (Betic Cordillera, southern Spain). Acta Geológica Hispánica 36 (3-4), 283-295.

Alfaro, P., Delgado, J., Sanz de Galdeano, C., Galindo Zaldívar, J., García Tortosa, F.J., López Garrido, A.C., López Casado, C., Marín, C., Gil, A.J., Borque, M.J. (2008): The Baza Fault: a major active extensional fault in the central Betic Cordillera (South Spain). International Journal of Earth Sciences 97, 1353-1365. doi:10.1007/ s00531-007-0213-Z

Alfaro, P., Gibert, L., Moretti, M., García-Tortosa, F.J., Sanz de Galdeano, C., Galindo-Zaldívar, J., López-Garrido, A.C. (2010): The significance of giant seismites in the Plio-Pleistocene Baza paleolake (S Spain). Terra Nova 22 (3), 172-179. doi:10.1111/j.13653121.2010.00930.x

Anderson, J.G., Wesnousky, S.G., Stirling, M.W. (1996): Earthquake size as a function of fault slip rate. Bulletin of the Seismological Society of America 86, 683-690.

Azañón, J.M., Azor, A., Booth-Rea, G., Torcal, F. (2004): Smallscale faulting, topographic steps and seismic risk in the Alhambra (Granada, SE Spain). Journal of Quaternary Science 19, 219-227. doi $>10.1016 / \mathrm{S} 0012-821 \mathrm{X}(03) 00632-0$.

Azañón, J.M., Tuccimei, P., Azor, A., Sánchez-Almazo, I.M., AlonsoZarza, A.M., Soligo, M., Pérez-Peña, J.V. (2006): Calcrete features and age estimates from U/Th dating: Implications for the analysis of Quaternary erosion rates in the northern limb of the Sierra Nevada range (Betic Cordillera, Southeast Spain). In: A.M Alonso-Zarza, L.H. Tanner (eds.), Paleoenvironmental Record and Applications of Calcretes and Palustrine Carbonates. Geological Society of America Special Paper: p. 223-239.
Banda, E., Gallart, J., García-Dueñas, V., Dañobeitia, J.J. y Markis, J. (1993): Lateral variation of the crust in the Iberian Peninsula: new evidence from the Betic Cordillera. Tectonophysics 221, 53-66. doi:10.1016/0040-1951(93)90027-H

Braga, J.C., Martín, J.M., Quesada, C. (2003): Patterns and average rates of late Neogene-Recent uplift of the Betic Cordillera, SE Spain. Geomorphology 50, 3-26. doi:10.1016/S0169-555X(02)00205-2

Calvache, M.L., Viseras, C., Fernández, J. (1997): Controls on fan development-evidence from fan morphometry and sedimentology; Sierra Nevada, SE Spain. Geomorphology 21, 69-84. doi:10.1016/ S0169-555X(97)00035-4

CSN (1998). Proyecto SIGMA. Análisis del estado de esfuerzos tectónicos, reciente y actual en la Península Ibérica. Report 10.1998. Consejo de Seguridad Nuclear, Madrid.

Díaz-Hernández J.L., Juliá R. (2006): Geochronological position of badlands and geomorphological patterns in the Guadix-Baza basin (SE Spain). Quaternary Research 65, 467-477. doi:10.1016/j. yqres.2006.01.009

Estévez, A., Sanz de Galdeano, C. (1983): Néotectonique du secteur central des Chaînes Bétiques (basins du Guadix-Baza et de Grenade). Revue de Géographie Physique et de Géologie Dynamique 21, 23-34.

Fernández-Ibáñez, F., Pérez-Peña, J.V., Azor, A., Soto, J.I., Azañón, J.M. (2010): Normal faulting driven by denudational isostatic rebound. Geology 38 (7), 643-646. doi:10.1130/G31059.1

Foucault, A. (1971): Étude géologique des environs des sources $d u$ Guadalquivir (province de Jaen et de Grenade, Espagne méridionale). $\mathrm{PhD}$. Thesis. University of Paris: $633 \mathrm{p}$.

Galindo-Zaldívar, J., Jabaloy, A., Serrano, I., Morales, J., GonzálezLodeiro, F., Torcal, F. (1999): Recent and present-day stresses in the Granada Basin (Betic Cordilleras): Example of a late Miocenepresent-day extensional basin in a convergent plate boundary. Tectonics 18, 686-702. doi:10.1029/1999TC900016

Galindo-Zaldívar, J., Gil, A.J., Borque, M.J., González-Lodeiro, F, Jabaloy, A., Marín-Lechado, C., Ruano, P., Sanz de Galdeano, C. (2003): Active faulting in the internal zones of the central Betic Cordilleras (SE, Spain). Journal of Geodynamics 36, 239-250. doi:10.1016/S0264-3707(03)00049-8

García-Tortosa, F.J., Sanz de Galdeano, C., Alfaro, P., Galindo-Zaldívar, J., López Garrido, A.C. (2007): La falla y los pliegues de Galera. In: C. Sanz de Galdeano, J.A. Peláez (eds.), La cuenca de Guadix-Baza. Estructura, tectónica activa, sismicidad, geomorfología y dataciones existentes. CSIC-Univ. Granada. Publ. Fac. Ciencias. Granada, 141-153.

García Tortosa, F.J., Alfaro, P., Galindo Zaldívar, J., Gibert, L., López Garrido, A.C., Sanz de Galdeano, C., Ureña, M. (2008a): Geomorphologic evidence of the active Baza fault (Betic Cordillera, South Spain). Geomorphology 97, 374-391. doi: 10.1016/j.geomorph.2007.08.007

García-Tortosa F.J., Sanz de Galdeano C., Alfaro P., Galindo-Zaldívar, J. (2008b): Deformación reciente de La Cuenca de Guadix-Baza. Geotemas 10, 1007-1010.

García Tortosa, F.J., Alfaro, P., Galindo Zaldívar J., Sanz de Galdeano, C. (2011): Glacis geometry as a geomorphic marker of recent tectonics: the Guadix-Baza Basin (South Spain). Geomorphology 125, 517-529. doi: 10.1016/j.geomorph.2010.10.021

Gibert, L., Ortí, F., Rosell, L. (2007): Plio-Pleistocene lacustrine evaporites of the Baza Basin (Betic Chain, SE Spain). Sedimentary Geology 200, 89-116. doi:10.1016/j.sedgeo.2007.03.003

Hanks, T.C., Kanamori, H. (1979): A moment-magnitude scale. Journal of Geophysical Research 84, 2348-2350.

Johnson, C., Harbury, N., Hurford, A.J. (1997): The role of exten- 
sion in the Miocene denudation of the Nevado-Filábride Complex, Betic Cordillera (SE Spain). Tectonics 16, 189-204. doi: 10.1029/96TC03289

Joyner, W.B., Fumal, T.E. (1985): Predictive mapping of earthquake ground motion. In: J.I. Ziony (ed.), Evaluating earthquake hazards in the Los Angeles region: an earth-science perspective. U.S. Geological Survey Profess. Paper 1360: p. 203-220.

Lhénaff, R. (1965): Néotectonique quaternaire sur le bord occidental de la Sierra Nevada (province de Grenade, Espagne). Revue de Géographie Physique et de Géologie Dynamique 2 (VII/3), 205-207.

Peláez, J.A., López Casado, C. (2002): Seismic hazard estimate at the Iberian Peninsula. Pure and Applied Geophysics 159, 2699-2713.

Peláez, J.A., Sanz de Galdeano, C., López Casado, C. (2003): Use of active fault data versus seismicity data in the evaluation of seismic hazard in the Granada Basin (Southern Spain). Bulletin of the Seismological Society of America 93: 1670-1678.

Pérez-Peña, J.V., Azañón, J.M., Booth-Rea, G., Azor, A., Delgado, J. (2009a): Differentiating geology and tectonics using a spatial autocorrelation technique for the hypsometric integral. Journal of Geophysical Research-Earth Surface 114: 1-15.

Pérez-Peña, J.V., Azañón, J.M., Azor, A., Tuccimei, P., Della Seta, M., Soligo, M. (2009b). Quaternary landscape evolution and erosion rates for an intramontane Neogene basin (Guadix-Baza basin, SE Spain). Geomorphology 106, 206-218. doi: 10.1016/j.geomorph.2008.10.018

Reicherter, K.R., Jabaloy, A., Galindo-Zaldívar, J., Ruano, P., BeckerHeimann, P., Morales, J., Reiss, S., González-Lodeiro, F. (2003): Repeated palaeoseismic activity of the Ventas de Zafarraya fault (S Spain) and its relation with the 1884 Andalusian earthquake. International Journal of Earth Sciences 92, 912-922. doi: 10.1007/ s00531-003- 0366-3.

Riley, C., Moore, J.McM. (1993): Digital elevation modelling in a study of the neotectonic geomorphology of the Sierra Nevada, southern Spain. Zeitschrift fur Geomorphologie N.F. 94, 25-39.

Rodríguez-Fernández, J.C., Sanz de Galdeano, C. (2006): Late orogenic intramontane basin development: the Granada basin, Betics (southern Spain). Basin Research 18, 85-102. doi: 10.1111/j.13652117.2006.00284.x

Ruano, P., Galindo-Zaldívar, J., Jabaloy, A. (2004): Recent tectonic structures in a transect of the Central Betic Cordillera. Pure and Applied Geophysics 161, 541-563. doi: 10.1007/s00024-003-2462-5

Ruiz, A.M., Ferhat, G., Alfaro, P., Sanz de Galdeano, C., Lacy, M.C., Rodríguez-Caderot, G., Gil, A.J. (2003): Geodetic Measurement of Crustal Deformation on NW-SE Faults of The Betic Cordillera, Southern Spain, 1999-2001. Journal of Geodynamics 35, 259-272. doi:10.1016/S0264-3707(02)00134-5

Santanach, P., Sanz de Galdeano, C. y Bousquet, J.C. (1980): Neotectónica de las regiones mediterráneas de España (Cataluña y Cordilleras Béticas). Boletín Geológico y Minero 91 92: 417440.
Sanz de Galdeano, C. (1983): Los accidentes y fracturas principales de las Cordilleras Béticas. Estudios Geológicos 39, 157-165.

Sanz de Galdeano, C. (2008): The Cádiz-Alicante Fault: an important discontinuity in the Betic Cordillera. Revista de la Sociedad Geológica de España 20, 49-58.

Sanz de Galdeano, C., López Garrido, A.C. (1999): Nature and impact of the Neotectonic deformation in the western Sierra Nevada (Spain). Geomorphology 30, 259-272. . doi:10.1016/S0169555X(99)00034-3

Sanz de Galdeano, C. Alfaro, P. (2004): Tectonic significance of the present relief of the Betic Cordillera. Geomorphology 63, 178-190 doi:10.1016/j.geomorph.2004.04.002

Sanz de Galdeano, C., Peláez, J.A. (2011): Fallas activas de la Cordillera Bética. Una aproximación a partir de la información tectónica y sísmica. Editorial Universidad de Granada, Granada: 287 p.

Sanz de Galdeano, C., Peláez Montilla, J.A., López Garrido, A.C (2001): La cuenca de Granada. Estructura, tectónica activa, sismicidad, geomorfología y dataciones existentes. CSIC-Univ. Granada. Publ. Fac. Ciencias. Granada, Granada: 218 p.

Sanz de Galdeano, C., Peláez, J.A., López Casado, C. (2003): Seismic potential of the main active faults in the Granada Basin (southern Spain). Pure and Applied Geophysics 160:,1537-1556. doi:10.1007/ s00024-003-2359-3

Sanz de Galdeano, C., Shanov, S., Galindo-Zaldívar, J., Radulov, A., Nikolov, G. (2010): A new tectonic discontinuity in the Betic Cordillera deduced from active tectonics and seismicity in the Tabernas Basin. Journal of Geodynamics 50, 57-66. doi:10.1016/j. jog.2010.02.005.

Sanz de Galdeano, C., García Tortosa, F.J., Alfaro, P., López Garrido, A.C., Delgado, J., Gibert, L. (2007): El anticlinal de Alfahuara-Botardo (sector de Orce-Huéscar, cuenca de Guadix-Baza, Cordillera Bética). In: C. Sanz de Galdeano, J.A. Peláez (eds.), La cuenca de Guadix-Baza. Estructura, tectónica activa, sismicidad, geomorfología y dataciones existentes. CSIC-Univ. Granada. Publ. Fac. Ciencias. Granada: 127-139.

Sanz de Galdeano, C., Galindo Zaldívar, J., López Garrido, A.C., Alfaro, P., Pérez Valera, F., Pérez López, A., García Tortosa, F.J. (2006): La falla de Tíscar: su significado en la terminación sudoeste del arco Prebético. Revista de la Sociedad Geológica de España 19, 271-280.

Scott, G., Gibert, L. (2009): The oldest hand-axes in Europe. Nature 461, 82-85. doi:10.1038/nature08214

Vera, J.A. (1970): Estudio estratigráfico de la depresión de GuadixBaza. Boletín Geológico y Minero 91, 429-462.

Viseras, C. (1991): Stratigraphy and Sedimentology of the alluvial fill in the Guadix Basin (Betic Cordilleras). PhD. Thesis. University of Granada: 327 p..

Wells, D.L. Coppersmith, K.J. (1994): New empirical relationships among magnitude, rupture length, rupture width, rupture area, and surface displacement. Bulletin of the Seismological Society of America 84, 974-1002. doi: 10.1785/ gssrl.78.1.78 